\section{Westinghouse Research Fellowships}

THE Westinghouse Electric and Manufacturing Co., of Pittsburgh, Pennsylvania, has established ten 'post-doctorate' fellowships for research in physics, including chemical physics and physical metallurgy, to enable investigators to carry on their work at the Westinghouse Research Laboratories in East Pittsburgh. Five fellows have been appointed for 1938-39, and five more will be appointed in each succeeding year. The objects of the Company in establishing the fellowships are: "(1) To make a worth-while contribution to the development of the fundamental sciences on which modern industry is based. The Company feels that all research leading to a better understanding of the nature of matter and energy will ultimately prc re valuable to technology even though its immedic te field of application is not apparent. (2) To en ible a group of able investigators to become familiar with the scientific problems confronting the electrical industry. It is felt that this contact will be of great value whether the men turn to industrial research or to academic work after completion of their fellowship period." Fellows will devote their entire time to work on their research projects, and will be under the general supervision of Dr. E. U. Condon, associate director for the programme of fundamental research. It is expected that they will also participate actively in the seminars and colloquia held at the Laboratories and in the neighbouring institutions of higher education. Appointments are made for a period of one year and a fellow is eligible for one reappointment for a like period. The salary is 2,400 dollars a year.

THE names of the first five Westinghouse Research Fellows, chosen from fifty applicants, are : Robert $O$. Haxby, University of Minnesota. Mr. Haxby has been a graduate student in physics for the last four years, and has participated actively in the nuclear physics research in the University of Minnesota. He will join the group which will carry on research in nuclear physics using the large high-voltage generator now being built in East Pittsburgh. John A. Hipple, Princeton University. Mr. Hipple has been a graduate student in physics at Princeton during the past four years, where he has worked with Prof. Walker Bleakney. He will design a large mass-spectrograph of high resolving power for studies in molecular structure in the Westinghouse Laboratories. Sidney Siegel, Columbia University. Dr. Siegel has carried out researches on elastic and magnetic properties of metals under the direction of Prof. S. L. Quimby. He hopes to develop methods of growing single crystals of pure metals and of alloys which show order-disorder transitions to study how the elastic properties of alloys depend on the arrangement of the atoms in the crystal lattice. W. E. Shoupp, University of Illinois. Dr. Shoupp is at present an instructor in physics at the University of Illinois, where he is actively engaged in studies on nuclear physics with the Illinois cyclotron. In addition to his work in nuclear physics, he has made several contributions to extreme ultra-violet spectroscopy as a collaborator of Prof. P. G. Kruger. At the Westinghouse Laboratories, he will continue studies in nuclear physics, working with Dr. W. H. Wells on the high-voltage generator. W. E. Stephens, California Institute of Technology. Mr. Stephens has done work in nuclear physics in the Kellogg Radiation Laboratory in Pasadena, where he studied the production of neutrons by bombarding boron and nitrogen with high-energy deuterons. He has also worked on the development of a new type of high. voltage discharge tube. In East Pittsburgh he will continue his researches on nuclear physics with the large generator at the Westinghouse Laboratories.

\section{Bronze Age Hoard from Bognor}

A bronze founder's hoard, which is dated at the early part of the first millennium B.c., has been brought to light at Flansham, near Bognor Regis. The find was made at a depth of about four feet at a point in Hoe Lane, a deep and ancient track now a lane, where it was joined by a new drive in course of construction. The objects discovered were distributed among several owners, but have been brought together again to be described by Mr. S. E. Winbolt in The Times of May 9. With six bronze implements were twenty-two lumps of copper, weighing $14 \mathrm{lb}$. Some round pieces of copper indicate a diameter of six inches for the complete cake, which would appear to have been cast in a crucible with a slightly concave bottom. This hoard is evidently the stock-in-trade of a bronze founder, such as has been discovered not infrequently in Britain. Mr. Winbolt recalls that a similar hoard was found in the course of road construction at Bognor some twelve years ago. The implements found with the copper are two socketed and looped celts, with square-mouthed socket openings, cast with a core, two socketed gouges, the top of a V-type sword with rivet holes, and the side of the top of a carp's tongue sword with a very sharp edge, which is compared with those of the Addington (Kent) and Beachy Head deposits. All may be dated at about 1000-750 B.c., and are probably a native product, though showing the influence of Spain and north-west France. It is to be noted that, as usual, there are no traces of tin with the copper. It is suggested that this, as well as the other and slightly earlier Bognor hoard, may have been abandoned or temporarily hidden, on account of the difficulties of a journey arising from the marshy character of the ground in this neighbourhood at the period.

\section{By-product Coking}

ON March 17, G. W. J. Bradley, in a paper presented to the Institute of Fuel, briefly reviewed the history of the coking industry from its inception at the beginning of the eighteenth century to the present day. This development has gradually culminated into a tendency for the industry to split into two sections, the section connected with iron and steel works and regarded as an auxiliary part of steel works technique and the section situated at the collieries. During the years 1934--37 orders have been placed by British steelworks for plants to 
carbonize approximately six and a half million tons of coal per year. This figure is equivalent to one third of the total carbonizing capacity of the industry. Naturally this prodigious increase in the number and capacity of plants provided by steelworks has deprived colliery-owned coke ovens of a large proportion of the market for furnace coke. Nevertheless, there is no cessation of coking at the collieries, as is apparent from the fact that, during the period 1934-37, 664 coke ovens were ordered by British collieries. So far as future developments of the industry are concerned, much depends upon the attitude adopted by coal owners and on the education of popular opinion towards a correct understanding of the principles involved. Carbonized fuel, whether solid or gaseous, is eminently suitable for domestic heating. The coal trade must be brought to realize this and steps should be taken to compensate for the inevitable loss of revenue which will follow the disappearance of raw coal from the domestic fuel market. Instead of fighting to retain raw coal in this market by raising the price of coal to those who make smokeless fuel, the coal trade should develop a widespread scheme of collaboration with producers of carbonized fuel. By-product coking is as fundamentally important an industry to the nation as a whole as is the coal industry, and as such it should be developed both technically and commercially with the greatest possible foresight.

\section{A Bridge Without Bolts or Rivets}

IT is stated in Electric Welding of February, a bi-monthly magazine published by the Quasi-Arc Co., Ltd., of London, that the London Passenger Transport Board has placed the contract for the building of a new bridge to carry the Hammersmith and City Railway over Ladbroke Grove, just outside Ladbroke Grove Station. The new bridge is to be of all-welded construction, and will be the first of its type and size in Great Britain. The present bridge has been in service for seventy years. The advantages of having a bridge without bolts and rivets are : the reduction of weight by one fifth, a substantial reduction of cost and much less noise during construction. The new bridge will be $60 \mathrm{ft}$. long; it will be built on three girders instead of two, and there will be a ballasted track instead of a timber track. These improvements will give much quieter running and also more steadiness and strength. It will be erected on trestles beside the present bridge, and early one Sunday morning the old structure will be rolled away and the new one rolled into place. Dr. Schaper, chief engineer of the German State Railways, stated in a paper last May read before a joint meeting of the Institution of Civil Engineers and the Institution of Structural Engineers that already at that time there were 150 all-welded railway bridges in service on the Reichsbahn up to spans of $177 \cdot 2 \mathrm{ft}$. At least as many all-welded bridges have been constructed in connexion with the new German arterial motor roads with spans nearly $100 \mathrm{ft}$. long. In Belgium nearly fifty welded bridges of the Vierendeel type up to spans of $295 \mathrm{ft}$. have been constructed over the Albert Canal. It seems certain that, in the future, welding will play an increasingly large part in the technique of construction.

\section{Safeguarding London's Water Supply}

Much information of considerable interest to the biologist and hygienist, chemist and bacteriologist is included in the thirty-first annual report of the Metropolitan Water Board, which contains the results of the chemical and bacteriological examinations of London waters during 1936, compiled by the Director of Water Examination, Lieut.-Colonel Harold (London: P. S. King and Son, Ltd. 10s. 6d.). The daily supply of water in 1936 averaged $287 \cdot 7$ million gallons, yielding 96.5 per cent of samples regarded as being of first-class quality. In the laboratories, 35,075 samples were examined in order to keep a watch upon the purity of the supply. In the Bacteriological Section investigations were conducted on the routine methods for the isolation and identification of Bacillus coli and allied bacteria, and on the isolation of $B$. paratyphosus B and of streptococci. Turbidity estimations, and the action on metals of tap-water before and after softening, have been investigated in the Chemical Section. Much trouble is sometimes caused in the reservoirs by the growth of Algæ, and the relation of chemical composition of the water to problems of algal production is one of the subjects investigated in the Biological Section. An interesting find was the blind well shrimp, Niphargus aquilex, which is naturally a subterranean species, but which has established itself in the filter beds at the Kempton Park Works. The report concludes with the tables containing the chief analytical results obtained.

\section{Transport of Tropical Fruits and Vegetables}

THE Imperial College of Tropical Agriculture, Trinidad, publishes, as Memoir No. 7, November 1937, a very valuable summary of the methods now avail. able to bring the produce of the tropics to the English markets, which goes far to explain the greater variety and interest of the window display of the green. grocer and the fruiterer throughout all the months of the year. Some 150 names of vegetables and fruits are listed-for many of these, as citrons, bananas and pineapples there is already much experience gathered and a long bibliography to cite, while others like mangoes and the papaw attract attention as household words of the tropics from which much is to be hoped if distance and time can be conquered; but so far their transport is evidently in the experimental stage. Many of the fruits and vegetables enumerated have been but names, if that, to dwellers in the temperate zones so far ; the litchi has arrived in much larger quantities lately and been much appreciated; the mangosteen and the langsat are still awaited. This list raises many hopes, and this concise summary of practical experience should prove of material value in enabling importers and transporters to learn how much has already been achieved and what possibilities there are for the future. Copies of this publication may be obtained (price 4s., British; 4s. 6d., foreign) on application to the Editor, Tropical Agriculture, Imperial College of Tropical Agriculture, Trinidad, B.W.I. 